\title{
ADDITIONAL WILDLIFE OBSERVATIONS ALONG THE SOURIS RIVER, MAY 1985
}

DONALD A. WEIDL, Box 607, Birch Hills, Saskatchewan. S0J 0G0

In the December 1985 issue of the Blue Jay the author summarised wildlife observations along the Souris River during three canoe trips; 1978, 1979, 1980. On 18-19 May 1985 Douglas Boivin, Terry Toews, Barb Weidl and the author returned to canoe part of the Souris River in the Oxbow area. On 18 May the party canoed $14 \mathrm{~km}$ downstream from Bow Valley Regional Park. On 19 May the canoes were launched at a point $8 \mathrm{~km}$ upstream from Bow Valley Regional Park with the day trip terminating at the park. The weather was clear on both days with temperatures ranging from $+10^{\circ} \mathrm{C}$ to $+23^{\circ} \mathrm{C}$ and winds west at $20-30 \mathrm{kmph}$.

A small dam downstream from the regional park provided sufficient water for the trip above the park on 19 May. Water levels downstream from the park were low but no major hazards, except the dam, were encountered. Lush tree cover along the river banks again provided good habitat for birds and other species of wildlife.

Muskrat, mink, Beaver, Raccoon, Coyote, Woodrhuck and White-tailed Deer were observed. No Fox Squirrels were seen during the 1985 outing. A total of 94 Western Painted Turtles were seen over the two days. Two Common Snapping Turtles were seen on 19 May, upstream from Bow Valley Regional Park. Again these turtles were very shy and it was only after a 30-minute wait that they briefly emerged, allowing a second look.

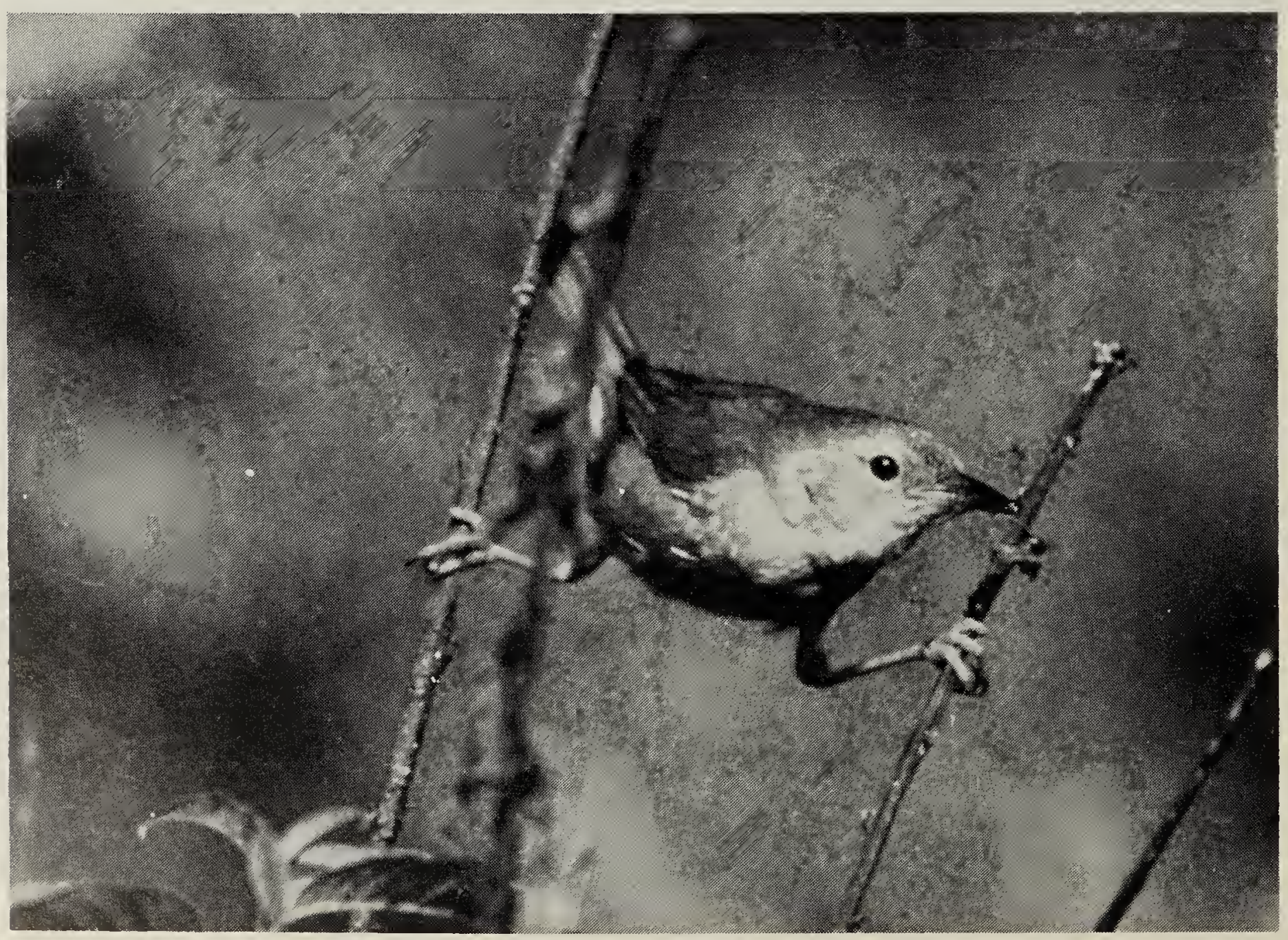


Altogether 77 bird species were observed during the two-day outing. This included birds seen along the immediate river bank as well as from some of the upper regions of the river valley. Of these, 14 were new species for our "all time list," making a total of 102 bird species recorded along the Souris River by the author. Table 1 lists the birds observed during the 1985 outing.

The author and members of the canoe trip were again impressed by the diversity of wildlife along the Souris River. If weather and time permit a fifth canoe trip is planned along a different section of the Souris River next spring.

Table 1. BIRD SPECIES OBSERVED ALONG THE SOURIS RIVER, 18-19 MAY 1985.

Species

* Double-crested Cormorant

Great Blue Heron

Wood Duck

Mallard

Northern Pintail

Blue-winged Teal

Northern Shoveler

American Widgeon

*Canvasback

* Lesser Scaup

Northern Harrier

Cooper's Hawk

Swainson's Hawk

Red-tailed Hawk

* American Coot

Killdeer

Solitary Sandpiper

Willet

Spotted Sandpiper

Upland Sandpiper

Franklin's Gull

Black Tern

Mourning Dove

Great Horned Owl

Belted Kingfisher

* Yellow-bellied Sapsucker

Downy Woodpecker

Hairy Woodpecker

Northern Flicker

*Olive-sided Flycatcher

Western Wood-Pewee

Least Flycatcher

Western Kingbird

Eastern Kingbird

Horned Lark

* Purple Martin

Tree Swallow

N. Rough-winged Swallow

\section{\# Seen Species}

\# Seen

2 Bank Swallow

4 Cliff Swallow

4 pair Barn Swallow

10 pair

1 pair

4 pair

1

3 pair

1 female

injured

1 pair

Blue Jay

Black-billed Magpie

American Crow

Black-capped Chickadee

* White-breasted Nuthatch

House Wren

* Eastern Bluebird

* Gray-cheeked Thrush

* Swainson's Thrush

American Robin

Brown Thrasher

Cedar Waxwing

Warbling Vireo

*Tennessee Warbler

* Orange-crowned Warbler

Yellow Warbler

*Blackpoll Warbler

Black-and-white Warbler

American Redstart

Northern Waterthrush

Common Yellowthroat

Rose-breasted Grosbeak

Rufous-sided Towhee

Chipping Sparrow

Clay-colored Sparrow

Vesper Sparrow

Song Sparrow

Bobolink

Red-winged Blackbird

Western Meadowlark

Brewer's Blackbird

Common Grackle

Brown-headed Cowbird

Northern Oriole

American Goldfinch

House Sparrow

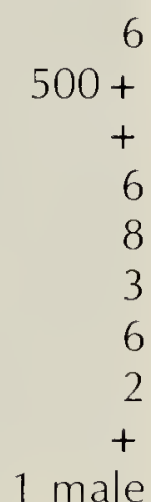

* = species added to our "all time list."

$+=$ more than 10 individuals seen over the two days. 